\title{
Dreaming a Better World through Literature: Positive Psychology in the Select Short Stories of Humayun Ahmed
}

\author{
K. M. Wazed Kabir ${ }^{1} \&$ Md. Shamim Mondol ${ }^{2}$ \\ ${ }^{1}$ Associate Professor and Chairman, Department of English, Green University of Bangladesh, Bangladesh
}

${ }^{2}$ Assistant Professor, Department of English, Green University of Bangladesh, Bangladesh

Correspondence: K. M. Wazed Kabir, Department of English, Green University of Bangladesh, Bangladesh, Email: chairman@eng.green.edu.bd

To cite this article: Kabir, K. M. W., \& Mondol, M. S. (2018). Dreaming a Better World through Literature: Positive Psychology in the Select Short Stories of Humayun Ahmed. American International Journal of Social Science Research, 3(1), 48-52. Retrieved from https://www.cribfb.com/journal/index.php/aijssr/article/view/221

Received: December 10, $2018 \quad$ Accepted: December 15, $2018 \quad$ Online Published: December 20, 2018

\begin{abstract}
Humayun Ahmed has been instrumental in guiding readership in Bangladesh with his profuse literary works for over forty years. He enjoyed in his life time and is still enjoying after death consistently unchallenged highest popularity. His acceptance among the readers specially the youth is due to his deeper understanding of the socio-cultural situations of post-independent Bangladesh and psyche of the people in general specifically the town dwelling middle class. His major focus in his writings is to bring out the lighter and brighter part to make life worth of living in every situation irrespective of its gravity. Both his novels and short stories stimulate a happier mood and purer mind through bringing out the positive aspects of life. This widely recognized area of Humayun goes well with the youngest branch of psychological studies, positive psychology. This paper is an attempt to study Humayun Ahmed's select short stories from the view point of positive psychology.
\end{abstract}

Keywords: Positive Psychology, Unchallenged, Understanding, Stimulate, Brighter

\section{Introduction}

Humayun Ahmed (1948-2012) was man of versatile talent and epical success in his career as a writer, dramatist, film maker and professor. He made his appearance in Bangla literature in 1972 with his debut novel Nondito Noroke (In Blissful Hell) written when he was a university student. With the first book, he got appreciation and acceptance from the critics and scholars. In his career over forty years, he penned over two hundred books with unmatched popularity and influence. "He is the most widely read writer in Bangla literature." (Murshid, 2012, 95). He wrote over hundred short stories and touched the major trends and significant issues in them. "Among them, there are the stories of the middle class, poor, the Liberation War, love, mystery, supernatural, science fictions, farce, children's story, ghost stories etc. Whatever may be the genre or theme, humanitarian aspects are prominent in most of his stories."(Rahman, 2012, p. 217) Some scholars, however, has considered his short stories as the most important of all his contributions and consider him one such a powerful story teller that can be unparalleled even in the world literature. Syed Shamsul Haq (2012) thinks, "Humayun Ahmed will cement his position longest for his short stories. Some of his short stories are unique in consideration of not only Bangla literature but also the world literature. He has sketched life impeccably." (Cited in Moom Rahman, p. 217)

2. Literature Review

Humayun Ahmed has been the maker of the dreams of the youth for decades in Bangladesh and he has successfully brought happiness in the life of the people plunged in crisis. His writings have been assessed and discussed by the scholars and critics often with general commentaries. Many of them find him a writer writing with a soul for human beings and their happiness. Hoque (2012) puts thus, "For forty years, he has built dreams of all people starting from seven and half crore to sixteen crore. ...He filled our period of growth with pleasure. He has molded our mind and built out taste and influenced our prose." (27-18) In his writings, he put to use diction unlike others in the history of Bangla literature and his language not only holds the emotion of the people but also influences others in writing lucidly for the people. Zaman focuses on the background in which 
Humayun wrote throughout his life. It was a trouble-torn society where problems creep up and boggle all in every step and the writer has succeeded in providing them a taste of life. He thinks, "The creations of Humayun Ahmed were done in the background of the all devouring despondency, unemployment, lack of democracy, depravation, emergence of autocrat and its oppressions, the urge of the youth to come out of this circle." (Zaman, 2012, p. 197) Humayun's contribution to add pleasure and happiness in the life of the people torn with problems and crisis is immense and the people can feel it quite easily. Saha (2012) thinks, "He has quenched the thirst of the people who see so many cruelties around and want a bit of smile and pleasure." (p. 177) Some critics also find humanitarian values in his narratives. Moom Rahman (2012) sees the writer unparalleled in weaving human soul in his stories. To her, "Humayun Ahmed is truly unparalleled and powerful in his humanitarian values and diverse style of expressions." (p. 233) While some writers have pinpointed the positive aspects in all the writings of the writer. Syed Shamsul Haq (2012) summarizes, "I can see three lights in the depth of Humayun Ahmed's writings: truth, purity and beauty. These three lights have enlightened his stories, novels, travelogues, memoirs, even the light hearted writings. But it is true that his readers remain busy with discovering entertainment through simplicity instead of that light." (p. 382) Mofidul Hoque finds him more significant as a writer than readers and critics think him to be. To him, Humayun Ahmed is a revolutionary who left the traditional way to deal with socio-political and cultural issues of the country and presented them in so diverse manners that often the people get baffled and can't realize his worth. He thinks, “The Bngalee showed great deficiencies in understanding his worth despite his enormous emotionalism and exuberance, and boundless love." (p. 170) He suggests deeper study of the writer for understanding more and more implications yet to be explored. This paper can contribute to add a new dimension to the study of the short stories of Humayun Ahmed and positive psychology can be the most fitting theoretical aspect for that exploration.

3. Positive Psychology: A Theoretical Perspective

Positive psychology as a new domain of psychology started its formal journey in 1998 when Martin Seligman as the president of the American Psychological Association chose this as the theme of his term and he along with Csikszentmihalyi (2000) define positive psychology as a "science of positive subjective experience, positive individual traits, and positive institutions promises to improve quality of life and prevent the pathologies that arise when life is barren and meaningless" (p. 5) The premises of this approach draw from humanistic psychology advanced by Abraham Maslow, Carl Rogers and others who came to prominence in mid-twentieth century and emphasized the realization and expression of every individual's capabilities and creativities, a process of self-actualization.

Since the devastation of the World War II, psychology concentrated more and more on repairing the damage in human functioning and healing them which downplay the fulfilled individual's perspective and flourishing community. Positive psychology fills in the gap by focusing more on building positive qualities for a life worth living. Its main focus is on eudaimonia, the good life which aims at a life more worthy and fulfilling. It can be seen as a reaction against the practices and premises of psychoanalysis and behaviorism which deal mainly with the negative psychological aspects to cure. In these practices, positive qualities like creativity, spirituality and hope are dealt negatively while positive psychology attempts "to understand and build the factors that allow individuals, communities, and societies to flourish". (Seligman, M. E., \& Csikszentmihalyi, M., 2014. p. 5) Positive psychology relies heavily on the scientific method in understanding the complex human behavior and problems. It takes into account both issues of repairing the worst as well as building the best. In the study of positive psychology, Seligman with his "Authentic Happiness Theory," and then "Well-being Theory", Mihaly Asikszentmihalyi with his theory of flow and Christopher Peterson's concept of Character Strengths and Virtues contributed in founding the base of this field. The workings of this approach are summarized in the following manner:

The field of positive psychology at the subjective level is about valued subjective experiences: well-being, contentment, and satisfaction (in the past); hope and optimism (for the future); and flow and happiness (in the present). At the individual level, it is about positive individual traits: the capacity for love and vocation, courage, interpersonal skill, aesthetic sensibility, perseverance, forgiveness, originality, future mindedness, spirituality, high talent, and wisdom. At the group level, it is about the civic virtues and the institutions that move individuals towards better citizenship: responsibility, nurturance, altruism, civility, moderation, tolerance, and work ethic.” (Seligman, M. E., \& Csikszentmihalyi, M., 2000, p. 5)

\section{Locating Positive Psychology in the Select Short Stories of Humayun Ahmed}

"Ekti Neel Botam" (“A Blue Button") is a short story anthologized in Premer Golpo (Love Stories) by Humayun Ahmed. It is about a relationship of a young man named Ronju working in an add farm with an aristocratic and wealthy family of Dhaka. He is inferior in his social, cultural and finical positions to the family. He puts it like this, "Who am I? Nobody. A meager man. I work in an add farm. I count every paisa of the small amount earn. And these people? I think, the guard standing at their gate is paid more than I do." (p. 75) He happens to come to this house with one of their relatives and is fascinated with the behavior of the pretty young girl of the house named Esha towards him. She appreciates his tall figure and makes him do a fancy work of fitting a nail. But she does not tell him the use of it and keeps it at suspense by telling him to come again and see. He takes it as a 
pretext to come here again, but he knows that is not necessary. When he comes again, he is afraid that they may not recognize him though he has a firm conviction because their house is always open. "Any one can come at any time. There is no barrier." (p. 75)

However, he is recognized by Esha's father who interacts with him and wants to know from him of the news about the country in a tone as if he were known for a long time, as if he were a knowledgeable person, as if he were an important man. Even Esha who is in a hurry and is going out, stops seeing him, repents for not being able to give him time, but still adds value to him by showing him the use of the nail he has fixed on the first visit. He hesitates whether he should go inside or not, Esha's father insists him to go. He finds a beautiful show piece having flowing light if electric connection is given. Thus he comes in contact with a positive old man, a pretty and positive young girl and a beautiful showpiece that he has never seen before. She tells him how they got it. She tells him of her father and his story telling pattern and informs him of their father-daughter relationship. She also gifts him a beautiful smile that brings a deep sigh and a thought, "I don't know who the lucky fellow who will get this girl all his life." (p. 76) The father too shares his views on life and the world which can be done with the intimate persons. This feeling of intimacy grows in Ronju. Positivity breeds positivity. Everything looks beautiful to him. He gets spontaneous invitation from them, "Come again." (p. 79) A great change comes over him and he dreams a better life. He stops gossiping with the friends who use nasty words about the girls and enjoy. He can no longer tolerate this nonsense. He gets admitted in a college at night shift to do his MA. He buys a new window screen, a mosquito net and a bed sheet. He manages a painting from an artist friend and whitewashes the walls of his room himself. His friends insinuates to the physical pleasure in that new setting. He asks himself, "In what darkness are they groping? Will they not come out of it?" (p.78)

He has his own philosophy of life which is better and brighter and full of positivity than before. His life changes as he gets a space to nurture his strength by changing the attitudes to life. Thus the writer shows a way where people of different classes can interact to bring a better change in the society through mutual respect.

Love affair is common among the youth and the break ups are also common which often makes one side embittered and frequently the incidents of acid throwing and physical tortures for refusal in affair are seen in our society. Humayun Ahmed deals with the issue delicately to change the view point of the youth. In the short story "Ekjon Kritodas" ("A Slave"), the writer has narrated a very simple and familiar story of a young couple who is supposed to get married on the day the story starts. The unnamed hero is waiting for his beloved Parul to go to his friend, Harun's house where they are to get married. Shocked hero gets back home and finds a slip left by Parul to call a land phone number. Being shattered, he spends the whole noon on bed and touches no food, and continues thinking that his relation with Parul is over. At the evening, he gets out and calls Parul. She talks in a very playful tone with the air of a child. She informs him of her getting a job in a kindergarten. When reminded of marriage, she in a very normal tone tells him to delay it. She adds in a spontaneous tone, "The state of your business is such these days that if we get married, we would have to eat a single meal a day." (p. 92) He understands that she will never marry him though they both made shopping in the New Market for arranging the room. He feels like killing himself but fails as he lacks the courage. He incurs consecutive loss in his business. He loses money as his friend who borrowed from him dies. He fails in all attempts and investment for business. He even takes pain in managing a decent life. He realizes, "Girls can conjecture well. Parul in the truest sense foresaw my future." (p. 92) This gives him space to justify Parul's stand. Communication slackens, and he never approaches her. But sometimes they meet, and every time Parul comes forward and shows every sympathy and feels genuinely shocked for the degraded health and business and shows courtesy by offering him tea. She even seeks his help in buying gift for her friend's son's birthday. She never mentions even mistakenly about their marriage. He gets surprised to see confident and vain Parul with her "post of a school master of three hundred taka." (p. 93)

He gets the news of her marriage in April and "almost forgives her for not showing cruelty by sending him invitation card." (p. 93) He feels relieved, enjoys a film, gossips with friends, and has the air as if nothing happened and what happened is happening on regular basis. He feels relieved and says,

That night the air in my room starts feeling warm and humid. I keep awake till mid night. Lying on bed, I gradually delve down in the thought that with a bit progress in my business, I will marry a simple girl with sad look. And I will guffaw while sharing Parul's story of heartlessness. (p. 93)

Thus he bounces back while he is supposed to be hard and harsh. The writer's attempt to show how to deal with the tough situations in adversary is obvious. His situation deteriorates and comes to a point when he has to sell all the fancy items like a three band Philips transistor, a record player and a table clock. Still one day he has to pass a day eating a bit of bread. He even starts feeling that the marginal people eating street side food are much happier. He does some petty jobs and Parul gets deleted from his memory. So the bitter days does not breed bitterness at all. Life must be welcome whatever may be the situation.

However, one day while passing by Mohammadpur Bazar, He sees a baby like a doll holding Parul's part of saree. He tries to avoid any meeting. Still "Just for a moment, it seems to him, this doll like girl could be his daughter." (p. 94) He gets back to reality thinking of his job in Sobhan Mia's Indenting Farm. He gets the job and attends office on foot, but he cannot enjoy at all. To him, "It is a boring, insipid life and while gets awake at 
mid night, I feel like dying." (94) He avoids the meeting with the familiar people. Still he sees Parul one day possibly with her husband and another day with another girl walking and laughing. He, however, has got transformed in look and body. So, even the most intimate people cannot recognize him. He is by then sure that Parul too will not be able to recognize him, but he fails. "Parul can recognize me in a moment. She stands confounded seeing me. She cannot speak for few moments." (p. 95) He inquires of Parul and tells her of his emergency to go away instantly. With surprise and sadness, she stares at him. When he takes steps forward, she only says, "You have reduced to such state!" (p.95) He tells her of his failure in business and seeks her permission to leave. "Parul says nothing in reply. I see with surprise, her eyes fill with tears. Turning her face to another direction, she stands for some time, and then leaves walking in an exhausted manner." (p. 95)

This tear does a lot for him. "I totally forgot Parul. Love affair is merely a trifle matter to the life which I am living. But Parul gets herself established with the few drops of her worthless tears." (p. 95) Love returns to his life. There is no sense of revenge, only reward. Humayun just reiterates Rabindranath's poem,

"He who looks up to me

With unfathomable forgiveness

All my depths and deficiencies

I'll sacrifice myself for him." (2013, 63)

The writer knows that the people of Bangladesh are happy not because they have desired affluence, rather because they have their own faith in something or somebody. With this faith and waiting, they have their own type of fulfillment. This mode of life with hope and dream has been explored by the writer. The short story "Ochin Brikkho" ("The Unknown Tree") is all about waiting for golden days of human beings in general and elongating that with optimism. There is a tree in a remote rural area which carries fairy tales of its own that once a witch was passing over the village. She felt thirsty and was quenched here. Feeling satisfied, she awarded them the tree asking them to take care of it. She said, "The tree will bear flower after a long time. You all will then be free of pangs and pains. The flowers of this tree are elixir. It will work if it is taken after a day's fasting." (121) It has earned great veneration for itself through a long nourished faith that once the tree yields flower, it will work as elixir, every ill one will be cured, poverty and suffering will disappear and all will be happy. But nobody knows when that time will come. But all people there in the village at least know it clearly, "The time to yield flowers have not come. Flowers will bloom in the right time. This tree takes much time for bearing flower." (p. 119)

The area is a remote one and the people are poor. They have their fight of life. The most important man among them is a primary school teacher who, "Seeing him at a glance, he looks like a man defeated in the struggle of life. He is alive because he has to." (p. 120) His wife is in death bed suffering from serious illness and he can do nothing as he has already sold all his property for her treatment. Still he is hopeful that she will be cured with the help of the tree. The people feel proud that the dignitaries come to the village for the tree. "The dignitaries come from the town to see the unknown tree, we feel very good. We get chance to meet the people of high esteem." (p. 120)

Humayun Ahmed has written over one hundred stories and all are with his magical touch of love and affection for human beings and the surroundings. His efforts are always with betterment of life and the society which instantly brings to mind the assumptions and aims of positive psychology.

5. Conclusion

The study shows how Humayun Ahmed has made use of his pen to portray the characters and themes in a positive light without any imposition of a humanitarian writer. He rather incites the potentials, makes them space to flourish, unenvelops the unexcavated parts of a personality and shows the way to make life worth living. His tasks go well with the positive psychologists who endeavor to make life better by throwing light on the positive psychological aspects and socio-cultural phenomenon. Humayun Ahmed's contribution is no less than a positive psychologist in reshaping the psyche of the people and boosting the best to advance in the better and pleasant track which shows his dreams of a better world through his literary works.

References

Ahmed, H. (2000), Premer Golpo (Love Story), Dhaka, Ananya.

Haq, Syed Shamsul. (2012), Humayun Ahmed, His Departure, In Humayn Ahmed: Souvenir, Dhaka: Anyaprokash.

Hoque, Anisul, (2012). The Maker of Our Dreams, In Humayn Ahmed: Souvenir, Dhaka: Anyaprokash.

Hoque, Mofidul, (2012), The Hero of Transforming the Form: Humayun Ahmed, In Humayn Ahmed: Souvenir, Dhaka: Anyaprokash.

Rahman, Moom, (2012), The Humanitarian Magician of Adorable Stories, In Humayn Ahmed: Souvenir, Dhaka: Anyaprokash.

Saha, Mahadev, (2012), Tears and Love for Humayun, In Humayn Ahmed: Souvenir, Dhaka: Anyaprokash.

Seligman, M. E., \& Csikszentmihalyi, M. (2000, January). Positive Psychology: An Introduction. American Psychologist. Vol. 55, No. 1, 5-14,

Seligman, M. E., \& Csikszentmihalyi, M. (2014). Positive psychology: An introduction. Springer Netherlands. 
Tagore, R. (2013), Shesher Kobita (The Last Poem), Dhaka, Bishwo Shahitto Kendro.

Zaman, Mahmud Al, (2012), A Few Words about Humayun Ahmed, In Humayn Ahmed: Souvenir, Dhaka: Anyaprokash.

\section{Copyrights}

Copyright for this article is retained by the author(s), with first publication rights granted to the journal.

This is an open-access article distributed under the terms and conditions of the Creative Commons Attribution license (http://creativecommons.org/licenses/by/4.0/) 